\title{
Selection indexes for improved weaning and marketing body weights of the Burundi local rabbits
}

\begin{abstract}
Summary
Estimates of genetic and phenotypic parameters for growth-related traits involving body weights at 4, 6 (weaning), 8 and 10 (marketing) weeks of age and average daily gains from 4- to 6-and 6-to 10-weeks of age (postweaning daily gain) were computed on 193 males of the Burundian local rabbits. Estimates were then used for constructing thirteen selection indexes, involyed body weights at 4,6 and 10 weeks of age and daily gains, to improve body weights of rabbits at weaning and marketing.

The use of weaning weight in an index combined with body weight at 4 weeks of age $\left(\mathrm{W}_{4}\right)$ and postweaning average daily gain (inde $x_{11}$ ) or postweaning daily gain solely (index ${ }_{12}$ ) resulted in a relative efficiency of about $100 \%$ as using weaning weight combined with body weights at 4 and 10 weeks of age (index ) or with marketing body weight (index $x_{2}$ ) or $W_{4}$ (index $x_{3}$ ). The accuracy of selection $\left(r_{T 1}\right)$ using these indexes ranged between 0.890 and 0.906 . They lead to a progress in weaning weight from $77-79 \mathrm{~g}$ and in marketing weight from $54-56 \mathrm{~g}$. However, from a practical stand point, selection on index 3 , including $\mathrm{W}_{4}$ and weaning weight, or on index 5 . including weaning weight alone, could be recommended for improving both weaning and marketing weights of Burundian local rabbits.
\end{abstract}

Key Words: body weight, genetic improvement, selection index, rabbits

\section{Zusammenfassung}

Titel der Arbeit: Selektionsindizes zur Verbesserung der Absetz- und Vermarktungsgewichte bei Lokalkaninchenrassen in Burundi

Es wurden genetische und phănotypische Parameter von Wachstumsmerkmalen wie die 4-, 6, 8 und 10 Wochengewichte sowie die täglichen Gewichtszunahmen von der $4,-6$, sowie der $6 .-10$, Woche an 193 Kaninchenböcken der Burundischen Lokalrasse geschătzt. Diese Parameter fanden Eingang in die Konstruktion yon 13 Selektionsindizes um eine Verbesserung der Vermarktungsgewichte zu erzielen. Es werden die verschiedenen Indizes beschrieben und deren Effizienz diskutiert. Aus praktischer Sicht erreichten Indizes, die das 4 Wochen- und 10 Wochengewicht oder ausschließlich das 10 Wochengewicht einbezogen, die großte Eflizienz.

Schlüsselwörter: Körpergewicht, genetische Verbesserung, Selektionsindizes, Kaninchen

\section{Introduction}

Small scale rabbit production involving minimal inputs, could make a substantial contribution to the supply of animal protein in developing countries. In Burundi, the objective of encouraging production of rabbit meat requires improvement of the productivity of its local breed, a one that is being kept mainly by farmers. To the author's knowledge, the unique attempt was made by the author himself (ANOUS, 2000) to improve meatiness of this breed using selection index. He reported that selection for the full index involving body weights at 4,6 and 12 weeks of age (i.e. initial, weaning and marketing body weight, respectively) is expected to lead to increase lean weight $(+34.8 \mathrm{~g})$ through acheving extra marketing body weight $(+56.1 \mathrm{~g})$ and higher percentage of lean $(+0.62 \%$ unit) with maximum accuracy of selection

\footnotetext{
'The author worked as Expert and Professor of Animal Production in Burundi from February 1993 to August 1996.
} 
equal 0.87 . However, the effect of this method of selection on growth-related traits (i.e. body weights and average daily gains) till marketing is still needed.

Therefore, the purposes of the present study are to quantify the genetic and phenotypic variation and covariation of growth-related traits in the local rabbits of Burundi, and to calculate the direct and correlated responses expected from selection for both weaning and marketing body weights, considered to be of prime interest to meat rabbit breeders in Burundi, using selection index.

\section{Material and methods}

Source of data. The data used in this study were collected during the period from February to June 1995 on 193 male Burundian local rabbits, progeny of 18 unrelated bucks and 46 unrelated does. They were raised at the experimental farm of the Institut Supérieur d'Agriculture (I.S.A.), Gitega (located approximately $1680 \mathrm{~m}$ above sea level), Burundi. Local rabbits are of small size and adult males and females weight about $1,7 \mathrm{~kg}$. Each doe was contributed 3 to 4 liters with unrepeated mating with the same buck.

Management and traits considered. Rabbits were identified at 3 weeks of age and weaned at the age of 6 weeks. From weaning up to marketing at 10 weeks of age, all animals were fed ad libitum on a $16 \%$ crude protein commercial pelleted ration containing $2600 \mathrm{Kcal}$ digestible energy/kg diet. Roughages and green grass were also provided. The body weights in grams at $4\left(\mathrm{~W}_{4}\right), 6\left(\mathrm{~W}_{6}\right), 8\left(\mathrm{~W}_{8}\right)$ and $10\left(\mathrm{~W}_{10}\right)$ weeks of age were recorded for each rabbit. Average daily gain from 4- to 6-weeks of age $\left(D_{4}\right.$ $\left.{ }_{6}\right)$ and postweaning average daily gain from 6 - to 10 -weeks of age $\left(\mathrm{DG}_{6-10}\right)$ were calculated $(\mathrm{g} / \mathrm{d})$.

Staristical analysis. Heritabilities and genetic and phenotypic correlations were estimated from the sire components of variance and covariance by the Least Squares and Maximum Likelihood program (HARVEY, 1990) according to the following model: where:

$$
Y_{i j K}=\mu+S_{i}+D_{i j}+E_{i j K},
$$

$$
\begin{aligned}
& Y_{i j k}=\text { the weight or average daily gain measured on the } k^{\text {th }} \text { animal of the } j^{\text {th }} \\
& \mu \quad=\text { the population mean for the trait } \mathrm{Y} \text {; } \\
& \mathrm{S}_{\mathrm{i}} \quad=\text { the random effect of the } \mathrm{i}^{\mathrm{th}} \text { sire }(\mathrm{i}=1,2, \ldots, 18) \text {; } \\
& D_{i j}=\text { the random effect of the } j^{\text {th }} \text { dam nested within the } i^{\text {th }} \text { sire }(j=1,2, \ldots \text {, } \\
& \text { 46); } \\
& \mathrm{E}_{\mathrm{ijK}}=\text { the random error assumed } \mathrm{NID} \sim\left(0, \sigma^{2} \mathrm{E}\right) \text {. }
\end{aligned}
$$

Estimates of heritability from the maternal half-sib correlations were less than zero for some traits. Therefore, only estimates calculated by paternal half-sib analysis were considered in the present study. As parity and litter size were not significant in a preliminary analysis $(\mathrm{P}>0.10)$, they were ignored in the final one .

Both weaning and marketing body weights were retained in the aggregate genotype with equal economic value (assumed to be 1). Body weights at 4,6 (weaning) and 10 (marketing) weeks of age together with daily gains from 4- to 6- and from 6- to 10 weeks of age were used in different combinations to compute thirteen selection indexes (CUNNINGHAM et al., 1970) to select for increased body weights at weaning and marketing. 
Results and discussion

Heritability estimates. The value of heritability estimates $\left(\mathrm{h}^{2}\right)$ for growth-related traits together with their standard errors (S.E.) are shown in Table 1.

Table 1

Mean $(\mathrm{X})$, phenotypic standard deviation $\left(\sigma_{\mathrm{p}}\right)$ and heritability $\left(\mathrm{h}^{2}\right)$ with its standard error ( \pm S.E.) for live performance traits (Mittelwert, Standardabweichung und $\mathrm{h}^{2}$-Werte der untersuchten Merkmale)

\begin{tabular}{lccc}
\hline \multicolumn{1}{c}{ Traits } & $\mathrm{X}$ & $\sigma_{\mathrm{p}}$ & $\mathrm{h}^{2} \pm$ S.E. \\
\hline Body weight ( $\mathrm{g}$ ) at: & 303 & 84.1 & $0.67 \pm 0.52$ \\
4-week ( $\left.\mathrm{W}_{4}\right)$ & 544 & 94.4 & $0.81 \pm 0.56$ \\
6-week; weaning body weight $\left(\mathrm{W}_{6}\right)$ & 732 & 89.8 & $0.98 \pm 0.60$ \\
8-week ( $\mathrm{W}_{\mathrm{g}}$ ) & 867 & 78.6 & $0.67 \pm 0.52$ \\
10-week; marketing body weight $\left(\mathrm{W}_{10}\right)$ & & & \\
Average daily gain (g/d) between: & 17.2 & 4.0 & $0.47 \pm 0.46$ \\
4- and 6-week (DG & & & \\
6- and 10-week; postweaning daily gain $\left(\mathrm{DG}_{6-10}\right)$ & 10.7 & 1.2 & $0.53 \pm 0.48$ \\
\hline
\end{tabular}

The value of $\mathrm{h}^{2}$ estimate for body weight increased with increasing age from 0.67 at 4week of age up to 0.98 at 8 -week of age, then it decreased. In agreement with the conclusion of previous reports reviewed by KHALIL et al. (1986), estimates of heritability for body weight were highest at younger ages, declining to the lowest values after weaning and increasing again at the older ages.

The $h^{2}$-value for body weight was higher at weaning than marketing (0.81 vs 0.67$)$. This agrees with the findings of MOSTAGEER et al. (1970) on Giza White rabbits $(0.185$ vs 0.150$)$ and KHALIL (1986) on Bouscat $(0.46$ vs 0.24$)$ and Giza White $(0.65$ vs 0.39$)$ breeds. The estimates of sire-component $h^{2}$ show that selection for body weight at earlier ages may be useful method for improving early rabbit growth.

Generally, the $h^{2}$ values obtained in the present study for the body weight at $4,6,8$ and 10 weeks of age were higher than those reported in the literature $(0.10$ to 0.55 at 4 weeks; MOSTAGEER et al., 1970; OUHAYOUN et al., 1973; EL-AMIN, 1974; CHEVALET, 1976; VRILLON et al., 1979; 0.185 to 0.650 at 6 weeks; MOSTAGEER et al., 1970; ALVAREZ et al., 1974; KHALIL, 1986; FERRAZ et al., 1991; 0.20 to 0.72 at 8 weeks; MOSTAGEER et al, 1970; EL-AMIN, 1974; KHALIL, 1986; 0.15 to 0.56 at 10 weeks; MOSTAGEER et al., 1970; OUHAYOUN et al., 1973; VRILLON et al., 1979; KHALIL, 1986; FERRAZ et al., 1991). This reflects the high contribution of the genetic additive variance to the total variance for body weights in this breed of rabbit compared to the other breeds.

The heritability estimates for the average daily body weight gain were moderate to high, but lower than those of body weight. They were higher between weaning and marketing than between $4-$ week of age and weaning $(0.53$ vs 0,47$)$. However, the range of $h^{2}$ values reported in the literature for these traits (0.13 to 0.31; MOURA et al., 1991 and KROGMEIER et al., 1994, respectively) indicates low to moderate contribution of the genetic additive variance to the total variance. Thus, using body 
weights for constructing selection indexes to increase both weaning and marketing body weights of rabbits in the present study will lead to more gain than using daily gains.

Genetic and phenotypic correlations. Estimates of genetic and phenotypic correlations among various growth-related traits are given in Table 2 .

Table 2

Genetic (above diagonal) and phenotypic (below diagonal) correlations among the live performance trails' (Genetische (oberhalb der Diagonalen) und phänotypische (unterhalb der Diagonalen) Beziehungen zwischen untersuchten Merkmalen)

\begin{tabular}{ccccccc}
\multicolumn{2}{l}{ untersuchten Merkmalen) } \\
\hline Traits & $\mathrm{W}_{4}$ & $\mathrm{~W}_{6}$ & $\mathrm{~W}_{8}$ & $\mathrm{~W}_{10}$ & $\mathrm{DG}_{4-6}$ & $\mathrm{DG}_{6-10}$ \\
\hline $\mathrm{W}_{4}$ & - & 0.90 & 0.94 & 0.79 & $0.20^{\mathrm{NS}}$ & -0.96 \\
$\mathrm{~W}_{6}$ & 0.81 & - & 0.98 & 0.94 & 0.61 & -0.98 \\
$\mathrm{~W}_{8}$ & 0.67 & 0.88 & - & 0.99 & 0.49 & -0.89 \\
$\mathrm{~W}_{10}$ & 0.63 & 0.82 & 0.95 & - & 0.67 & -0.77 \\
$\mathrm{DG}_{4-6}$ & $-0.13^{\mathrm{NS}}$ & 0.48 & 0.49 & 0.45 & - & -0.50 \\
$\mathrm{DG}_{6-10}$ & -0.51 & -0.59 & -0.31 & $-0.15^{\mathrm{NS}}$ & -0.23 & - \\
\hline
\end{tabular}

NS: not significant $(P>0.05)$.

The genetic correlations among body weights were generally higher than the phenotypic correlations. They were all positive, so that rabbits more heavy at given age tended also to be more heavy at any later age. The lowest values obtained were between body weight at 4 -week of age and marketing body weight $\left(\mathrm{r}_{\mathrm{G}}=0.79\right.$ and $\mathrm{r}_{\mathrm{P}}=$ 0.63 ). This agrees with the conclusion reported by KHALIL et al. (1986). Thus, rabbit body weight at earlier ages can be used for selection to improve its body weight at later ages.

The genetic correlations between body weights and average daily gains were also higher than the phenotypic correlations. Genetically and phenotypically, the relation was positive among body weights and average daily gain from 4-to 6-weeks of age, while negative with average daily gain from weaning to marketing. This opposition in sign may indicate that, in rabbits, body weight before weaning is subjected to a large maternal influence, while it was influenced after weaning by the environmental factors (ex. ration, climat, etc).

Body weight at 6 weeks of age was highly correlated both genetically and phenotypically to body weight at $4\left(\mathrm{r}_{\mathrm{G}}=0.90\right.$ and $\left.\mathrm{r}_{\mathrm{p}}=0.81\right)$ and $10\left(\mathrm{r}_{\mathrm{G}}=0.94\right.$ and $\mathrm{r}_{\mathrm{p}}=$ 0.82 ) weeks of age, indicating that weaning weight could replace alone the two other body weights $\left(\mathrm{W}_{4}\right.$ and $\left.\mathrm{W}_{10}\right)$ as an index trait.

The basic traits in the aggregate genotype $\left(\mathrm{W}_{6}\right.$ and $\left.\mathrm{W}_{10}\right)$ showed large and positive genetic relationships with the other growth-related traits; the relationship was negative with postweaning average daily gain $\left(\mathrm{r}_{\mathrm{G}}=-0.98\right.$ and -0.77 , respectively). This indicates that selection for increasing body weights at weaning and marketing should affect positively body weights at other ages and negatively postweaning daily gain.

Selection indexes. Thirteen selection indexes arranged in three strategies (i, ii and iii), according to the use of one or a combination of body weights and average daily gains, were constructed. The weighing factors (b-values) and correlations of the indexes with the total aggregate genotype ( $r_{\pi}$ values) are given in Table 3 . 
Table 3

Weighing factors (b-values) and accuracy of selection in absolute $\left(R_{T 1}\right)$ and relative (RE) values in indexes used to improve both weaning and marketing body weights (Wichtungsfaktoren (b-Werte), absolute $\left(R_{T 1}\right)$ und relative (RE) Werte bei unterschiedlichen Strategien in den verschiedenen Indizes)

\begin{tabular}{|c|c|c|c|c|c|c|c|c|c|}
\hline \multirow{2}{*}{ Strategy ${ }^{*}$} & \multirow{2}{*}{$\begin{array}{l}\text { Index } \\
\text { No. }\end{array}$} & \multirow{2}{*}{ Source of information } & \multicolumn{5}{|c|}{ b-values } & \multirow{2}{*}{$r_{\pi}$} & \multirow{2}{*}{$\frac{\mathrm{RE}}{\%}$} \\
\hline & & & $\mathrm{W}_{4}$ & $\mathrm{~W}_{6}$ & $W_{10}$ & $\mathrm{DG}_{4-6}$ & $\overline{\mathbf{D G}_{6-10}}$ & & \\
\hline \multirow[t]{7}{*}{$\mathbf{i}$} & 1 & $W_{4}, W_{6}, W_{10}$ & -0.02 & 1.12 & 0.41 & - & 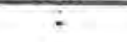 & 0.899 & 100.00 \\
\hline & 2 & $W_{60} W_{10}$ & - & 1.10 & 0.42 & - & - & 0.899 & 100,00 \\
\hline & 3 & $\mathrm{~W}_{4}, \mathrm{~W}_{6}$ & -0.06 & 1.43 & - & - & - & 0.890 & 99.00 \\
\hline & 4 & $W_{4}, W_{10}$ & 0.59 & - & 1.11 & - & - & 0.844 & 93,88 \\
\hline & 5 & $\mathrm{~W}_{6}$ & - & 1.38 & - & - & $\rightarrow$ & 0.880 & 97,89 \\
\hline & 6 & $W_{10}$ & - & - & 1.51 & - & - & 0.802 & 89.21 \\
\hline & 7 & $\mathrm{~W}_{4}$ & 1.24 & - & - & - & - & 0.709 & 78.87 \\
\hline \multirow[t]{3}{*}{ ii } & 8 & $\mathrm{DG}_{4-6}, \mathrm{DG}_{6-10}$ & - & - & - & 26.74 & -62.35 & 0.868 & 96.55 \\
\hline & 9 & $\mathrm{DG}_{4-6}$ & - & - & - & 30.88 & - & 0.842 & 93.66 \\
\hline & 10 & $\mathrm{DG}_{6.10}$ & - & $=$ & - & - & -83.67 & 0,658 & 73.19 \\
\hline \multirow[t]{3}{*}{ iii } & 11 & $\mathrm{~W}_{4}, \mathrm{~W}_{6}, \mathrm{DG}_{6-10}$ & $-0,10$ & 1.26 & - & - & -26.30 & 0.906 & 100.78 \\
\hline & 12 & $\mathrm{~W}_{6}, \mathrm{DG}_{6-10}$ & - & 1,20 & - & - & -25.96 & 0.905 & 100.67 \\
\hline & 13 & $W_{4}, D_{6-10}$ & 0.88 & - & - & - & 51.01 & 0.788 & 87.65 \\
\hline
\end{tabular}

Using body weights alone in an index (strategy i) showed that selection on index 1 , including $\mathrm{W}_{4}, \mathrm{~W}_{6}$ and $\mathrm{W}_{10}$ is theoretically capable of predicting the aggregate genetic value of an animal 0.90 as accurately as a perfect index $\left(\mathrm{r}_{\mathrm{TI}}=0.899\right)$. Assuming the efficiency of index $\mathrm{I}$ to be $100 \%$, the omission of $\mathrm{W}_{4}$ or $\mathrm{W}_{10}$ from index 1 (indexes 2 and 3 , respectively) resulted in practically the same value of $r_{T}$ as index $1\left(r_{T I}=0.899\right.$ and 0.890 , respectively). The relative efficiency of the reduced indexes including $W_{6}$, $\mathrm{W}_{10}$ or $\mathrm{W}_{4}$ alone (indexes 5,6 and 7) were $97.89,89.21$ and $78.87 \%$, respectively. Using index 5 , including $\mathrm{W}_{6}$ solely, leads practically to the same value of $\mathrm{r}_{\mathrm{TI}}$ as with indexes 1,2 and $3\left(\mathrm{r}_{\mathrm{TI}}=0.880\right)$.

In terms of selection efficiency, the use of average daily gains solely in an index (strategy ii) would not be as promising as the use of body weights alone (strategy i) or body weights combined with daily gains (strategy iii). Using $\mathrm{W}_{6}$ combined with $\mathrm{W}_{4}$ and postweaning daily gain (index 11) or with postweaning daily gain (index 12) resulted in a relative efficiency of about $100 \%$ as using indexes 1,2 and 3 .

From a practical standpoint, selection on index 3 including $W_{4}$ and $W_{6}$ or on index 5 including $\mathrm{W}_{6}$ alone could be considered as the best for improving both weaning and marketing body weights of Burundian local rabbits since their application is earlier compared to the use of indexes 1 and 2 (involving $W_{10}$ measured at later stage of the animal life), and easier compared to the use of indexes 11 and 12 (involving postweaning daily gain).

The effect of the different indexes was calculated as the expected improvement in both weaning and marketing body weights as well as correlated response in the other growth-related traits when selection on indexes 1 to 13 and the results are given in Table 4.

Generally, selection using body weights alone (indexes 1 to 7) or combined with postweaning daily gain (indexes 11 to 13) gave the greatest progress in marketing body weight, especially when $\mathrm{W}_{6}$ was involved (from 42 to $56 \mathrm{~g}$ ), while selection using daily gains alone (indexes 8 to 10 ) gave the lowest improvement (from 30 to $40 \mathrm{~g}$ ). On the other hand, selection using daily gains gave the greatest progress in weaning weight (from 61 to $102 \mathrm{~g}$ ), especially when $\mathrm{DG}_{4-6}$ was involved, however selection 
using body weights alone or combined with daily gains gave the same improvement in weaning weight (from 63 to $79 \mathrm{~g}$ ).

Table 4

Expected genetic changes in growth-related traits when using indexes to improve both weaning and marketing body weights ( intensity of selection $=1,00$ ) (Erwarteter genetischer Gewinn in den Wachstumsmerkmalen bei unterschiedlichen Strategien in den verschiedenen Indices)

\begin{tabular}{|c|c|c|c|c|c|c|c|c|}
\hline \multirow{3}{*}{ Strategy ${ }^{+}$} & \multirow{3}{*}{$\begin{array}{l}\text { Index } \\
\text { no. }\end{array}$} & \multirow{3}{*}{ Source of information } & \multicolumn{6}{|c|}{ Expected genetic change for: } \\
\hline & & & \multicolumn{2}{|c|}{$\begin{array}{l}\text { The traits in } \\
\text { aggregate genotype }\end{array}$} & \multicolumn{4}{|c|}{ the related traits } \\
\hline & & & $\overline{W_{6}}$ & $W_{10}$ & $\overline{\mathrm{W}_{4}}$ & $\mathrm{~W}_{\mathrm{s}}$ & $\mathrm{DG}_{4-6}$ & $\overline{D G_{G-10}}$ \\
\hline \multirow[t]{6}{*}{ i } & $\mathbf{I}$ & $W_{1}, W_{6}, W_{10}$ & 76.7 & 55.9 & 54.8 & 100.0 & 1.5 & -0.7 \\
\hline & 2 & $W_{6}, W_{10}$ & 76.7 & 55.8 & 54,9 & 100,2 & 1.6 & -0.7 \\
\hline & 3 & $W_{4}, W_{6}$ & 76.8 & 54.5 & 55.3 & 99.4 & 1.4 & -0.8 \\
\hline & 4 & $W_{4}, W_{10}$ & 71.0 & 53.4 & 53.6 & 99.3 & 2.9 & -0.6 \\
\hline & 5 & $\mathrm{~W}_{6}$ & 76.8 & 54.4 & 55.8 & 100.1 & 1.5 & -0.8 \\
\hline & 6 & $W_{10}$ & 65.7 & 52.6 & 44.5 & 86.6 & 1.5 & -0.5 \\
\hline & 7 & $W_{4}$ & 62.9 & 41.6 & 56.4 & 97.1 & 4.5 & -0.7 \\
\hline \multirow[t]{3}{*}{ ii } & 8 & $\mathrm{DG}_{4.6}, \mathrm{DG}_{6.10}$ & 102.3 & 40.4 & 95.5 & 78.0 & 1.9 & -0.5 \\
\hline & 9 & $\mathrm{DG}_{4-6}$ & 94.6 & 29.6 & 94.6 & 65.1 & 1.9 & -0.3 \\
\hline & 10 & $\mathrm{DG}_{6-10}$ & 61.2 & 35.9 & 47.9 & 57.1 & 1.0 & -0.6 \\
\hline \multirow[t]{3}{*}{ iii } & 11 & $\mathrm{~W}_{4}, \mathrm{~W}_{6}, \mathrm{DG}_{6-10}$ & 79.1 & 54.5 & 57.5 & 96.9 & 1.3 & -0.8 \\
\hline & 12 & $\mathrm{~W}_{6}, \mathrm{DG}_{6-10}$ & 79.1 & 54.3 & 58.2 & 98.0 & 1.5 & -0.8 \\
\hline & 13 & $\mathrm{~W}_{4}, \mathrm{DG}_{6.10}$ & 71.4 & 44.8 & 60.4 & 91.2 & 3.4 & -0.7 \\
\hline
\end{tabular}

i: Using body weights alone; it: Using daily gains alone; iii: Using daily gains combined with body weights.

The decreasing in post weaning average daily gain of rabbits is much less when daily gains alone in an index (from -0.3 to $-0.6 \mathrm{~g} / \mathrm{d}$ ) compared to the use of body weights alone (from- 0.5 to $-0.8 \mathrm{~g} / \mathrm{d}$ ) or body weights combined with daily gains (from -0.7 to $-0.8 \mathrm{~g} / \mathrm{d}$ ). Selection on all indexes is expected to increase all the other growthrelated traits differently.

The index incorporating body weights at 4,6 and 10 weeks of age (index 1) gave the greatest progress in marketing body weight $(+56 \mathrm{~g})$ as well as the reduced index involving body weights at weaning and marketing (index 2), however a moderate progress in weaning weight $(+77 \mathrm{~g})$ was observed with their use. On the other hand, the index incorporating $D_{4^{-6}}$ alone (index 9) or together with postweaning daily gain (index 11) gave the greatest progress in weaning weight $(+95$ and $+102 \mathrm{~g}$, respectively) with a small progress in marketing body weight $(+30$ and $+40 \mathrm{~g}$, respectively). The indexes $3,5,11$ and 12 gave about the same improvement in both weaning and marketing weights, and also the same improvement in the other growthrelated traits. The magnitude of the amount of progress in growth-related traits is comparable with this obtained using index 1 or 2 . Therefore, using one or more than one of the above mentioned indexes would lead to the same progress in growth-related traits.

Taking into consideration the expected genetic changes in growth-related traits as well as in weaning and marketing body weights, it appears more practical to the Burundian farmer to use the index including weaning weight alone (index 5) or combined with body weight at 4 - week of age (index 3 ) for improving efficiently both weaning and marketing body weights of rabbits since their application is earlier. The use of these 
indexes should result in a genetic increase in weaning and marketing body weights of 77 and $54 \mathrm{~g}$, respectively after one round of selection.

In conclusion, this study points out that selection index is a useful tool to improve growth performance of Burundian local rabbits without imposing more charge on production costs.

\section{References}

ALVAREZ, H.V.; DIAZ, G.V. DE; VARELA, A.G. DE:

ANOUS, M.R.:

Certain genetic parameters of weights in rabbits. J. Anim. Sci., 39 (1974), 151-152

Genetic improvement of meatiness of local rabbits in Burundi. Egypt. J, Rabbit Sci., 10 (2000) 2, 183 . CHEVALET, C.:

Estimation of phenotypic variance components for an inbred population. II. Application. Ann. Géné Sélec. Anim., 8 (1976), 207-232

CUNNINGHAM, E.P.; MOEN, R.A.; GJEDREM, T.;

EL-AMIN, F.M.:

Restriction of selection indexes. Biometrics, 26 (1970), $67-74$

A selection experiment for improvement of weight gains and feed conversion efficiency in rabbits.
Ph.D. Thesis, Dissertation Bristol Univ., UK. 1974

HARVEY, W.R. P.

Genetic parameters for weight and carcass traits of rabbits. J. Appl. Rabbit Res., 14 (1991), 187-192

LSMLMW Mixed Least Squares and Maximum Likelihood Computer Program PC-2 Version. Dairy KHALIL, M.H.E.: Estimation of genetic and phenotypic parameters for some productive traits in rabbits. Ph. D. Thesis,
Fac. of Agric. at Moshtohor, Zagazig Univ., Egypt. 1986

KHALIL, M. H.; OWEN, J.B.; AFIFI, E.A.:

A review of phenotypic and genetic parameters associated with meat production traits in rabbits. Anim. Breed. Abst., 54 (1986), 725-749

KROGMEIER, D,; DZAPO, V.; MAO, 1.L.:

Additive genetic and maternal effects on postweaning growth and carcass traits in rabbits. J. Anim. Breeding and Genetics, 111 (1994), 289-297

MOSTAGEER, A.; GHANY, M.A.; DARWISH, H.I.:

Genetic and phenotypic parameters for the improvement of body weight in Giza rabbits. U.A.R. J. Anim. Prod., 10 (1970), 65-72

MOURA, A.S.A.M.T.; POLASTRE, R.; Carmclo, M.J.:

Genetic5 A.S.A.M.T., POLASTRE, R. and CARMCLO M.J., 1991. Genetic study of individual performance from weaning to slaughter in Selecta rabbits. J. Applied Rabbit Res., 14 (1991), 228-234

OUHAYOUN, J.; ROUVIER, R.; VALIN, C; LACOURT, A.;

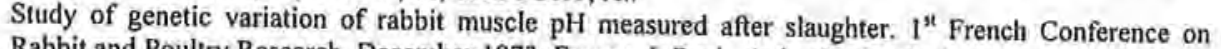
Rabbit and Poultry Research, December 1973, France. J. Rech. Avic. Cunic., Paris, comm. IV 2 .

VRILLON, J.L.; DONAL, R.; POUJARDIEU, B.; ROUVIER, R.; THEAU, M.; DUZERT, R.; CENTIS, A.;
ROUSTAN, A.: Selection and testing of sire lines of rabbits for terminal crossing , 1972-1975. Bulletin Technique, Département de Génétique Animale, Institut National de la Recherche Agronomique No. 28, 106p.
1979

Received: 1999-06-17

Accepled: $2000-12-07$

Author's address

Dr. M. REDA ANOUS

Department of Animal Production, Faculty of Agriculture, Ain Shams University,

P.O. Box 68 Hadayek Shoubra, 11241 Cairo, Egypt

E-Mail: anous53@hotmail.com 


\title{
Buchbesprechung
}

\author{
Veterinärmedizinische Neurologle \\ MARC VANDEVELDE, ANDRE JAGGY und JOHANN LANG
}

Parey Buchverlag Berlin, 2001, 2., neubearbeitete und erweiterte Auflage, 280 Seiten, 148 Abbildungen, 38 Tabellen, ISBN 3-8263-3224-5, Preis: 75,67 EUR

In den zurdickliegenden Jahren hat sich die Disziplin Neurologie in der Veterinărmedizin von einem Randgebiet zu einem bedeutsamen Spezialgebiet entwickelt. Diesem Trend und dem Bedurfnis nach immer besseren Dienstleistungen in der Praxis Rechnung tragend haben die Herausgeber der Veterinarmedizinischen Neurologie nunmehr die zweite, neubearbeitet und erweiterte Auflage der Monographie auf den Markt gebracht. Das Buch ist in erster Linie an Praktiker und Studierende der Veterinărmedizin gerichtet. Im Teil 1 wird der Leser vertraut gemacht mit dem neurologischen Untersuchungsgang, der speziesulbergreifend beschrieben wird. Es schließt sich eine Übersicht zur Klassifikation neurologischer Erkrankungen an. Den Abschluss dieses allgemeinen Teils bildet ein Kapitel uber spezielle Untersuchungsmethoden. Dabei liegt der Schwerpunkt bei den bildgebenden Verfahren. Die Teile II bis V behandeln, geordnet nach Lokalisationen, neurologische Erkrankungen bei Kleintieren, Pferden, Wiederkăuem und Schweinen. Aussagefahige Abbildungen, Schemata und Tabellen ergănzen in geeigneter Weise den Text. Ein Literaturverzeichnis ausgewahlter Fundstellen am Ende eines jeden Kapitels erlaubt es interessierten Lesern, tiefer und detaillierter in bestimmte Sachgebiete einzudringen. Insgesamt stellt das Buch die Diagnose und Therapie neurologischer Erksankungen bei Haus- und Nutztieren unter Praxisbedingungen übersichtlich dar. Der Tierarzt wird in die Lage versetzt, die Neurologie als Bestandteil der tierärztlichen Tatigkeit entsprechend den Notwendigkeiten und Bedurfnissen erfolgreich zu praktizieren. 